\title{
Renal cell carcinoma with peritoneal carcinomatosis in a mare
}

\section{Leonardo Pereira Mesquita ${ }^{1}$ Francisco Duque de Mesquita Neto $^{2}$ Mary Suzan Varaschin ${ }^{3}$ Angélica Terezinha Barth Wouters ${ }^{3}$ Flademir Wouters ${ }^{3^{*}}$}

\footnotetext{
${ }^{1}$ Departamento de Patologia, Faculdade de Medicina Veterinária e Zootecnia, Universidade de São Paulo (USP), São Paulo, SP, Brasil. ${ }^{2}$ Setor de Patologia Clínica, Departamento de Medicina Veterinária, Universidade Federal de Lavras (UFLA), Lavras, MG, Brasil. ${ }^{3}$ Setor de Patologia Veterinária, Departamento de Medicina Veterinária, Universidade Federal de Lavras (UFLA), CP 3037, $37200-000$, Lavras, MG, Brasil. E-mail: flademir@ufla.dmv.br. "Corresponding author.
}

ABSTRACT: Renal cell carcinoma, especially with extensive involvement of peritoneal cavity, is rarely described in horses. This study described a case of renal cell carcinoma in an 8-year-old mare, which presented with an enlargement in the left flank, decreased appetite and straining to defecate. Clinically, a tumor in the left retroperitoneal space was detected by rectal examination and ultrasonography. The animal died after one month of clinical evolution. At necropsy, the left kidney was completely effaced by a 50cm in diameter, irregular, round, lobulated cystic mass with necro-hemorrhagic areas. Within the peritoneal cavity, there was severe hemoperitoneum and numerous sessile and pedunculated masses ranging from 2.0 to $15.0 \mathrm{~cm}$ diameter that were attached to the visceral and parietal peritoneum. Histologically, the primary neoplasia and its metastasis were composed by a proliferation of epithelial cells, which were arranged in a tubulopapillary pattern. Diagnosis of renal cell carcinoma with peritoneal carcinomatosis and hemoperitoneum was based on macroscopic aspects, and mainly on the histological features.

Key words: equine, renal neoplasia, pathology, kidney, tumor.

Carcinoma renal associado à carcinomatose peritoneal em uma égua

RESUMO: Carcinomas renais, principalmente aqueles com extenso envolvimento da cavidade peritoneal são raramente descritos na espécie equina. Este trabalho tem por objetivo descrever um carcinoma renal com carcinomatose peritoneal em um equino, fêmea, de oito anos de idade, que apresentava aumento de volume no flanco esquerdo, hiporexia e dificuldade para defecar. Clinicamente, um tumor localizado no espaço retroperitoneal esquerdo foi detectado por meio de palpação retal e exame ultrassonográfico. Após um mês de evolução clínica, o animal veio a óbito. Macroscopicamente, o rim esquerdo estava completamente obliterado por uma massa de 50,0cm de diâmetro, irregular, lobulada e com áreas císticas e necro-hemorrágicas. Na cavidade peritoneal, havia hemoperitônio acentuado e inúmeras massas sésseis e pedunculadas, de 2,0 a 15,0 cm de diâmetro, estavam aderidas às porções parietal e visceral do peritônio. Histologicamente, a neoplasia primária e suas metástases eram constituídas principalmente pela proliferação de células epiteliais, as quais formavam estruturas túbulopapilares. O diagnóstico de carcinoma renal com carcinomatose peritoneal, associado a hemoperitônio foi baseado nos achados macroscópicos e, principalmente, histológicos da neoplasia.

Palavras-chave: equinos, neoplasia renal, patologia, rim, tumor.

Primary renal neoplasms are uncommon to rare in domestic animals (CIANCOLO \& MOHR, 2016). In horses, renal tumors account for approximately $0.011 \%$ of total tumors and renal cell carcinomas (RCC) represented half of these renal tumors (HASCHEK et al., 1981). Metastasis of equine RCC is common and has been reported in the lungs, liver, bone, contralateral kidney, heart, pancreas, intestine, adrenal glands, myocardium, and lymph nodes (BROWN \& HOLT, 1985; WEST \& KELLY, 1987; WISE et al., 2009). Involvement of the peritoneal cavity (carcinomatosis) in cases of RCC has been rarely reported (HASCHEK et al., 1981; VAN MOL \& FRANSEN, 1986). The aim of the present study is to describe the clinical and pathological findings of a RCC with peritoneal carcinomatosis in a mare.

An 8-year-old mixed-breed mare from Lavras, Minas Gerais, Brazil, with a one-month history of an enlargement in the left flank, decreased appetite, and straining to defecate was referred to a private veterinarian. A large, firm, irregular and multilobulated mass within the left retroperitoneal space was detected by rectal examination. Transabdominal ultrasound examination revealed a mass composed of multiple variable-sized cystic areas. The mare was found dead five days after clinical evaluation.

Grossly, the oral, conjunctival and vulvar mucous membranes were markedly pale. 
The abdominal cavity contained approximately 10L of partially coagulated blood. The left kidney was completely effaced by an irregular, round and lobulated mass measuring $50 \mathrm{~cm}$ in diameter that was partially covered by blood clots (Figure 1A). On cut surface, the mass was white to tan and had areas of hemorrhage and necrosis intermingled with multiple variable-sized cystic areas containing moderate amount of a viscous yellow material. Numerous pedunculated, sessile and irregular masses measuring from 2 to $15 \mathrm{~cm}$ in diameter were attached to the visceral and parietal peritoneum, mainly of the liver capsule, greater and lesser omentum, and serosa of large intestine (Figure 1B). The right kidney was mildly compressed by the largest mass. Tissue samples were fixed in 10\% neutral buffered formalin, processed routinely for histology, and stained with hematoxylin and eosin (H\&E).

Histological evaluation of the left renal mass revealed effacement of the renal architecture by a multilobulated, moderately cellular proliferation, which rarely infiltrated the surrounding fibrous capsule. The mass was composed of cuboidal and polygonal cells arranged in elongated tubular structures with multifocal papillary projections into the lumen supported by a fine fibrovascular stroma (Figure 1C-D). The tubular lumina were occasionally dilated (cystic areas) and often contained a moderate amount of homogeneous eosinophilic material. The tubular structures were lined by 1 to 4 layers of epithelial cells with indistinct cell borders and with a moderate amount of eosinophilic, often vacuolated cytoplasm. Nuclei were round to oval, centrally located, with finely stippled chromatin and one variably distinct basophilic nucleolus. Anisocytosis and anisokaryosis were mild (less than 1.5 times variation in size). There were 3 mitotic figures in 10 400X fields. Rarely, cells were arranged in a solid pattern. Within the central area of the mass there were multiple and locally extensive areas of necrosis and hemorrhage. Tumor cells were not visualized within lymphatics or blood vessels. The numerous pedunculated masses were morphologically similar to the main left renal mass. Cells within the masses in the abdominal cavity were restricted to the peritoneal surface and did not infiltrate adjacent tissues. All other evaluated organs, including ovaries, uterus, right kidney and urinary bladder, were within normal limits.

Based on the pathological findings, renal cell carcinoma with peritoneal carcinomatosis and severe hemoperitoneum was diagnosed. The left renal mass was histologically characterized by a proliferation of epithelial cells arranged in a tubulopapillary pattern. Diagnosis of renal neoplasia is usually straightforward by routine light microscopy (TRUONG \& SHEN, 2011). In domestic animals, the terms papillary, tubular and solid are used to refer to the predominant histological pattern (MEUTEN, 2002). In some cases, different histological patterns can occur in the same neoplasm (MEUTEN, 2002), as observed in the present case. The main differential diagnosis for the present case is transitional cell carcinoma of the renal pelvis, which can be differentiated histologically from RCC primarily by the presence of elongated and irregular tubules that usually occur in the latter (MEUTEN, 2002). Other differential diagnoses for the present case are neoplasms that cause transcoelomic metastasis such as mesotheliomas and carcinomas arising from the ovaries, transitional epithelium, biliary ducts and gastric mucosa (MEUTEN, 2002).

In horses and humans, abdominal carcinomatosis due to RCC has been rarely reported (HASCHEK et al., 1981; VAN MOL \& FRANSEN, 1986; PÉREZ GARCÍA et al., 1999). In humans, peritoneal involvement in RCC accounts for less than $1 \%$ of patients with metastatic disease (PÉREZ GARCÍA et al., 1999). In the present report, intraparenchymal metastasis were not detected, as well as evidence of lymphatic or vascular invasion in the main neoplasm. However, there was an extensive involvement of the peritoneum with numerous pedunculated masses attached to the peritoneal surface. The abdominal carcinomatosis observed in the present case was due to implantation of exfoliated cells from the main neoplasm to the peritoneal surface rather than invasion of lymphatics or blood vessels. The behavior of RCCs cannot be determined only based on cellular morphology (MEUTEN, 2002). In the present case, neoplastic cells did not exhibit prominent malignancy features. However, evidence of metastasis, lymphatic and vascular invasion, or infiltration to adjacent tissues might be helpful for classifying this tumor as benign or malignant.

Clinical signs in horses affected by RCC are usually nonspecific and appear in later stages of the disease (WISE et al., 2009). The most frequently reported clinical signs are weight loss, colic, and hematuria (WISE et al., 2009). The mare of the present report had decreased appetite and straining to defecate. The sudden death of the mare of the present report was most likely due to hypovolemic shock as a consequence of hemoperitoneum. Death resulting from hemoperitoneum has been reported in horses with RCC (BROWN \& HOLT, 1985; KNOWLES et 


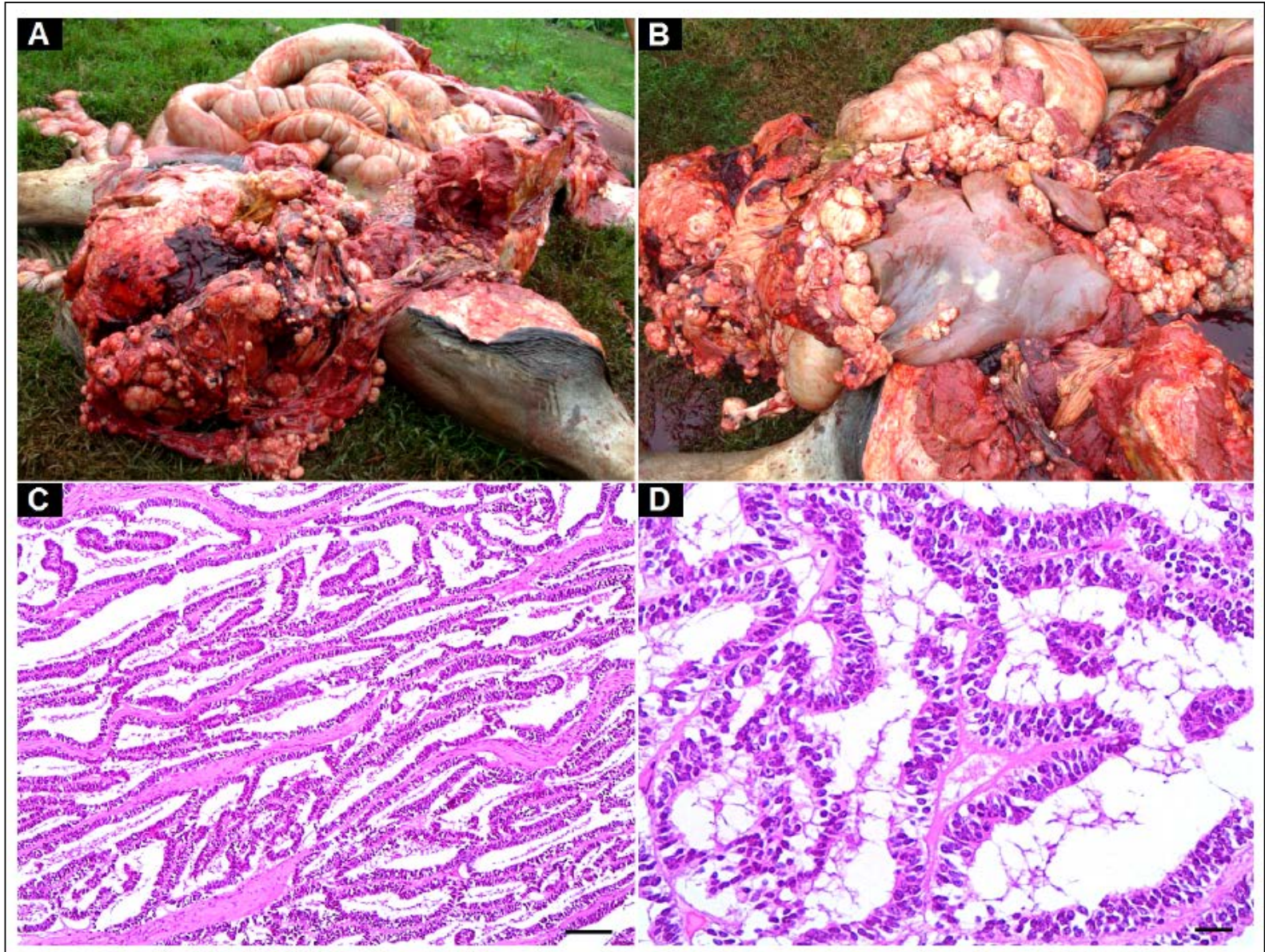

Figure 1 - Renal cell carcinoma with peritoneal carcinomatosis in an 8-year-old mare. A. The renal mass is $50 \mathrm{~cm}$ in diameter, white to tan and lobulated and covered by blood clots. B. In the abdominal cavity, numerous sessile and pedunculated variable-sized masses are widespread throughout the peritoneum, mainly on the hepatic capsule, and greater and lesser omentum. C. The tumor is composed by tubular structures with multifocal papillary projections into the lumen, $\mathrm{H} \& \mathrm{E}$ stain, bar $=100 \mu \mathrm{m}$. D Tubular structures are lined by 1 to 4 layers of cuboidal and polygonal neoplastic cells on a fine fibrovascular stroma. There is a mild amount of an amorphous, homogeneous eosinophilic proteinaceous fluid within the lumen. Some neoplastic cells have a vacuolated cytoplasm. H\&E stain, bar $=20 \mu \mathrm{m}$.

al., 2008). Intra-abdominal hemorrhage was detected through abdominocentesis in $21 \%$ of 14 horses with RCC (WISE et al., 2009). The affected kidney of the mare in the present report was covered by large amounts of blood clots. However, the precise origin of intra-abdominal hemorrhage could not be determined during necropsy. The most common source of hemoperitoneum in horses with RCC is the rupture of the affected kidney leading to intraabdominal hemorrhage (BROWN \& HOLT, 1985; KNOWLES et al., 2008).

\section{REFERENCES}

BROWN, P.J.; HOLT, P.E. Primary renal cell carcinoma in four horses. Equine Veterinary Journal, v.17, n.6, p.473-
477, 1985. Available from: <http://onlinelibrary.wiley.com/ doi/10.1111/j.2042-3306.1985.tb02561.x/abstract>. Accessed: May 17, 2016. doi: 10.1111/j.2042-3306.1985.tb02561.x.

HASCHEK, W.M. et al. Primary renal cell carcinoma in two horses. Journal of the American Veterinary Medical Association, v.179, n.10, p.992-994, 1981.

KNOWLES, E.J. et al. Renal carcinoma as a cause of sudden death in an aged horse. Equine Veterinary Education, v.20, n.9, p.452-455, 2008. Available from: <http://onlinelibrary.wiley.com/ doi/10.2746/095777308X334275/abstract>. Accessed: May 17, 2016. doi: $10.2746 / 095777308 \times 334275$

CIANCOLO, R.E.; MOHR, F.C. Urinary system. In: MAXIE, M.G. Jubb, Kennedy and Palmer's pathology of domestic animals. St. Louis: Elsevier, 2016. V.2, Cap.4, p.376-464.

MEUTEN, D.J. Tumors of the urinary system. In: MEUTEN DJ. Tumors in domestic animals. Iowa: Iowa State, 2002. Cap.10, p.509-546. 
PÉREZ GARCÍA, F.J. et al. Renal cell carcinoma. Clinical onset with peritoneal carcinomatosis. Report of a case. Actas Urológicas Españolas, v.23, n.2, p.156-159, 1999.

VAN MOL, K.A.C; FRANSEN, J.L.A. Renal carcinoma in a horse. Veterinary Record, v.119, n.10, p.238-239, 1986. Available from: $<$ http://veterinaryrecord.bmj.com/content/119/10/238.abstract $>$. Accessed: May 17, 2016. doi: 10.1136/vr.119.10.238.

TRUONG, L.D.; SHEN, S.S. Immunohistochemical diagnosis of renal neoplasms. Archives of Pathology \& Laboratory Medicine, v.135, n.1, p.92-109, 2011. Available from: <http://www. archivesofpathology.org/doi/10.1043/2010-0478-RAR.1?url ver=Z39.88-2003\&rfr_id=ori:rid:crossref.org\&rfr_dat $=$ cr_ pub\%3dpubmed>. Accessed: May 17, 2016. doi: 10.1043/20100478-RAR.1.

WEST, H.J.; KELLY, D.F. Renal carcinomatosis in a horse. Equine Veterinary Journal, v.19, n.6, p.548-551, 1987. Available from: <http:// onlinelibrary.wiley.com/doi/10.1111/j.2042-3306.1987.tb02671.x/abstract>. Accessed: May 17, 2016. doi: 10.1111/j.2042-3306.1987.tb02671.x.

WISE, L.N. et al. A retrospective analysis of renal carcinoma in the horse. Journal of Veterinary Internal Medicine, v.23, p.913-918, 2009. Available from: <http://onlinelibrary.wiley.com/doi/10.1111/ j.1939-1676.2009.0326.x/abstract;jsessionid=307BDA6A60F797 93440468CB192CA1CB.f02t02>. Accessed: May 17, 2016. doi: 10.1111/j.1939-1676.2009.0326.x. 